\title{
Estimation of carbon dioxide assimilated in shoot biomass of mature Acacia seyal (Del.) Brenan and Eucalyptus microtheca (F.) Muell
}

\author{
Hasabelrasoul Fadlelmula Mustafa ${ }^{1 *}$ and Bello Rufa'i Wali ${ }^{2}$ \\ ${ }^{1}$ Faculty of Forest Sciences and Technology, University of Gezira, PO Box 20 Medani, Sudan \\ ${ }^{2}$ Department of Environmental Science and Natural Resources, Faculty of Agricultural Sciences, University of \\ Gezira, PO Box 20 Medani, Sudan
}

*Corresponding Author: hasabelrasoul56@ hotmail.com

[Accepted: 28 January 2020]

\begin{abstract}
It was determinately proved that $\mathrm{CO}_{2}$ emission has been causing a paramount effect in climate change and hence global warming. The major effort that could mitigate the adverse impact is to expand in the forestation programs. Today, Sudan has lost in two decades (1990-2010) about $6,432,000$ hectares of its forests, which significantly reduced the number of surviving trees to absorb $\mathrm{CO}_{2}$. However, Sudan's data on tree species efficiency in assimilating $\mathrm{CO}_{2}$ is limited. Hence, the objective of this study was to estimate the amount of $\mathrm{CO}_{2}$ assimilated by shoot biomass of two tree species widely used in plantation programs in Sudan; Acacia seyal and Eucalyptus microtheca. The non-destructive sampling method of data collection was used in this research in November 2016, when all the trees held their leaves. That was in Umbarona Forest for A. seyal and Alamelhuda Forest for E. microtheca, both in the vicinity of Medani Town in central Sudan. One hundred samples of rectangular layout were randomly selected for each species. The diameter at breast height $(\mathrm{cm})$ and total tree height $(\mathrm{m})$ were measured. A recommended procedure to estimate green shoot biomass $(\mathrm{kg})$ and sequestered $\mathrm{CO}_{2}(\mathrm{~kg})$ was adopted. Accordingly, the green biomass weight was estimated on the basis of the formula; $\mathrm{W}=0.25 \mathrm{D}^{2} \mathrm{H}$ for $\mathrm{D}<11 \mathrm{~cm}$ and $\mathrm{W}=$ $0.15 \mathrm{D}^{2} \mathrm{H}$ for $\mathrm{D} \geq 11 \mathrm{~cm}$. Two models correlated the diamter at breast height $(\mathrm{DBH})$ and height $(\mathrm{h})$ of the trees to the weight of $\mathrm{CO}_{2}$ sequestered (wcs). A. seyal had the highest magnitude of sequestered $\mathrm{CO}_{2}$ as it was estimated at 370 ton/hectare, and that for E. microtheca was 176 ton/hectare. The correlation analysis applied to test the significance of two models (wcs $=a+b . h$ and wcs $=\mathrm{a}+\mathrm{b} . \mathrm{DBH})$ on the estimated amount of $\mathrm{CO}_{2}$ sequestered in both species revealed that the model $w c s=a+b D B H$ was the best predicting model as it retained $93 \%$ of the coefficient of determination $\left(\mathrm{R}^{2}\right)$ for E. micotheca and $68 \%$ for A. seyal. In conclusion, A. seyal was the most efficient in $\mathrm{CO}_{2}$ sink, despite the fact that it is a deciduous tree while E. microtheca is an evergreen tree. However, if the felling cycle will consider, six year for E. micotheca and 20 years for $A$. seyal and E. microtheca will be the most efficient in $\mathrm{CO}_{2}$ sink. The diameter at breast height was the most interpreting biophysical parameter for assimilated $\mathrm{CO}_{2}$ stock estimation. Establishing more forest plantations, supporting forestry agencies, implementing strong policies and improving public awareness on forest conservation as a natural carbon sink are recommended.
\end{abstract}

Keywords: Sequestration - Correlation - Biomass - Plantation.

[Cite as: Mustafa HF \& Wali BR Estimation of carbon dioxide assimilated in shoot biomass of mature Acacia seyal (Del.) Brenan and Eucalyptus microtheca (F.) Muell. Tropical Plant Research 7(1): 14-19]

\section{INTRODUCTION}

The climate change phenomenon is getting today's utmost global concern and there is an alarm shouting to reduce the gases emission, especially carbon dioxide $\left(\mathrm{CO}_{2}\right)$. The plant in general and forests in particular play a vital role in the global carbon circle. However, the situation over the world calls upon each country to enormously consider the process of carbon sequestration in its plantations and forest management programs. The actual rate of carbon sequestration varies with species, climate and site (Tahoor et al. 2016, Aryal et al. 
2017, Babu \& Parthasarathy 2019). The living biomass of trees, the understory vegetation and the deadwood constitute the primary carbon pool in forests (Kuimi \& Jayakumar 2012, Vivek \& Parthasarathy 2015, Abetu \& Bekele 2019). In this formation, the above-ground biomass of the tree is mainly the largest carbon pool, and it is directly affected by deforestation and degradation. Hence, estimating the tree carbon stocks is primarily important to assess the magnitude of carbon exchange between the trees and the atmosphere (Rowntree \& Nowak 1991, Johnson \& Abrams 2009, Vashum \& Jayakumar 2012).

The expansion of agriculture in Sudan, such as Gezira Scheme since 1925, was occurred at the direct expense of forests. Large amounts of woodland had been cleared in the development of the Gezira Scheme cotton farming (Bernal \& Victoria 1997). In 1992 a ministerial decree was issued in Sudan to plant 5\% of the area of the irrigated schemes and $10 \%$ of the rainfed schemes by trees for just environmental functions. This decree was ignored since that time, but today and due to the drastic implications of accelerating deforestation rate of the dryland forests, especially those related to climate change and global heating, the Forests National Corporation and allied programs of some international agencies concerned with carbon sequestration and natural resources sustainable management are imparked on wide and extended forestation programs in the dryland of the Sudan under both irrigated and rainfed environments. This is also because the number of trees available to absorb carbon dioxide through photosynthesis has been greatly reduced (Falkowski et al. 2000). The species selection choices for the prevailing both irrigated and rainfed environment in central Sudan are restricted to two major tree species; Acacia seyal (Del.) Brenan and Eucalyptus microtheca (F.) Muell. Both species are of enormous wood and non-wood uses and paramount influences on the environment but they are contrasted in their phonological rhythm; A. seyal is deciduous with wide spherical crown and E. microtheca is evergreen with very narrow crown. A. seyal has bipinnate leaves while $E$. microtheca has simple narrow leaves. Both species are managed on rotation at 20 years for A. seyal (Dafa-Alla \& Abidallha 2014) and six years for E. microtheca (Badi et al. 1989).

Assessment of the amount of carbon dioxide sequestered by a tree gives us an estimate of the quantity of carbon emitted into the atmosphere when a particular tree is deforested or degraded. Furthermore, it helps us to quantify the carbon stocks that in turn may enable us to understand the current status of carbon stocks and also drive the near-future changes in the carbon stocks (Vashum \& Jayakumar 2012). Such research was not conducted in the Sudan before; therefore, this research aimed to bridge the gap of knowledge and the overall goal of the study was to estimate the amount of $\mathrm{CO}_{2}$ assimilated by shoot biomass of A. seyal and E. microtheca, which are widely used in plantation programs in Sudan.

\section{MATERIALS AND METHODS}

The study was conducted in two forests; natural Acacia seyal forest (Umbarona) and Eucalyptus microtheca plantation (Alamalhuda), both were in central Sudan in the neighborhood of Medani Town. During the year of study (2016-2017) the environment was characterized by average temperature of $38^{\circ} \mathrm{C}$ in summer and $24^{\circ} \mathrm{C}$ in winter, total rainfall was $165 \mathrm{~mm}$ and the soil is heavy clay soil. Umbarona forest was grown at random spacing and there were about 1190 trees per hectare while Alamalhuda was planted at $2 \times 3 \mathrm{~m}$ spacing to grow 1715 trees per hectare.

To collect reliable data, 100 samples were laid in each forest in a systematic way in rectangular plots, each of $100 \mathrm{~m}^{2}$ in area. Non-destructive method of data collection was used in this research. The height (h) and diameter at breast height (DBH) were two measurements for biophysical parameters of each tree using Haga altimeter and the ordinary Caliper, respectively. In case of tree with several stems, each one was measured separately. The method recommended by Chavan \& Rasal (2010) and Eneji et al. (2014) was applied, with slight modifications, into two steps to measure biomass and $\mathrm{CO}_{2}$ sequestered as followed:

Step (1): Estimation of shoot biomass:

$$
\begin{aligned}
& \mathrm{D}<11: \mathrm{W}=0.25 \mathrm{D}^{2} \mathrm{H} \\
& \mathrm{D} \geq 11: \mathrm{W}=0.15 \mathrm{D}^{2} \mathrm{H}
\end{aligned}
$$

Where, $\mathrm{D}=$ Diameter of the stem at breast height $(\mathrm{cm}) ; \mathrm{W}=$ Shoot biomass weight of the tree $(\mathrm{kg})$; and $\mathrm{H}=$ Height of tree (m).

Then dry shoot biomass was calculated by multiplying the tree biomass weight by $72.5 \%$ (Chavan \& Rasal 2010).

Step (2): Fixed carbon weight:

It was calculated by multiplying the dry shoot biomass of the tree by $50 \%$.Then sequestered carbon dioxide was determined by multiplying the weight of carbon in each tree by 3.666 , which is the ratio of $\mathrm{CO}_{2}$ to $\mathrm{C}$ www.tropicalplantresearch.com 
(Birdsey 1992).

Analysis using the model [wcs $=\mathrm{a}+\mathrm{DBH} \times \mathrm{h}$ ] was carried out to construct a fitted line correlating diameter at breast height $(\mathrm{DBH})$ and height $(\mathrm{h})$ of the trees to the weight of $\mathrm{CO}_{2}$ sequestered (wcs).

\section{RESULTS AND DISCUSSION}

Growth characteristics and $\mathrm{CO}_{2}$ sequestered in Acacia seyal and Eucalyptus microtheca trees were shown in Table 1. There were no significant variations between the trees in both species as far as the height and diameter were considered. That was not the case when the shoot biomass and hence carbon and fixed $\mathrm{CO}_{2}$ were arbitrated. The mean weight of sequestered $\mathrm{CO}_{2}$ by a single $A$. seyal tree was $304 \mathrm{~kg}$ to produce 370 ton/hectare while that of E. microtheca was $100 \mathrm{~kg}$ per tree and 176 ton/hectare. It was clear that $A$. seyal had twice the weight of $\mathrm{CO}_{2}$ sequestered as compared to E. microtheca. That was predicted to exist due to the difference in management practices and species type. A. seyal is managed by clear felling at 20 years rotation while $E$. microthecais commercially used to be felled at six years. However, this variation that seems to favor A. seyal will diminish if the rotation period is perceived; three crops of E. microtheca will be harvested during the rotation of A. seyal. Moreover, E. microtheca is evergreen while A. seyal is deciduous flushes the leaves during the rainy season which is very short in prevalence. This means that E. microtheca continues to fix $\mathrm{CO}_{2}$ all the year around, the growth rhythm that could outride the amount of $\mathrm{CO}_{2}$ fixed by A. seyal.

Table 1. Growth characteristics and $\mathrm{CO}_{2}$ sequestered in Acacia seyal (Del.) Brenan and Eucalyptus microtheca (F.) Muell grown, respectively in Umbarona and Alamahuda forests in central Sudan. Measurements were taken in November 2016 and given here on a tree basis

\begin{tabular}{lrrrr}
\hline Attribute & \multicolumn{2}{c}{ Acacia seyal } & \multicolumn{2}{c}{ Eucalyptus microtheca } \\
\cline { 2 - 5 } & Mean & $\mathbf{\pm S D}$ & Mean & $\mathbf{\pm S D}$ \\
\hline Height $(\mathrm{m})$ & 8.0 & 1.6 & 9.0 & 1.2 \\
Diameter at breast height $(\mathrm{cm})$ & 23.2 & 5.6 & 11.0 & 3.9 \\
Shoot biomass weight $(\mathrm{kg})$ & 229.0 & 102.2 & 75.4 & 47.2 \\
Dry shoot biomass weight $(\mathrm{kg})$ & 165.1 & 74.1 & 113.6 & 34.0 \\
Weight of carbon $(\mathrm{kg})$ & 102.4 & 37.1 & 27.2 & 17.2 \\
Weight of $\mathrm{CO}_{2}(\mathrm{~kg})$ & 304.3 & 135.8 & 100.2 & 62.9 \\
\hline
\end{tabular}

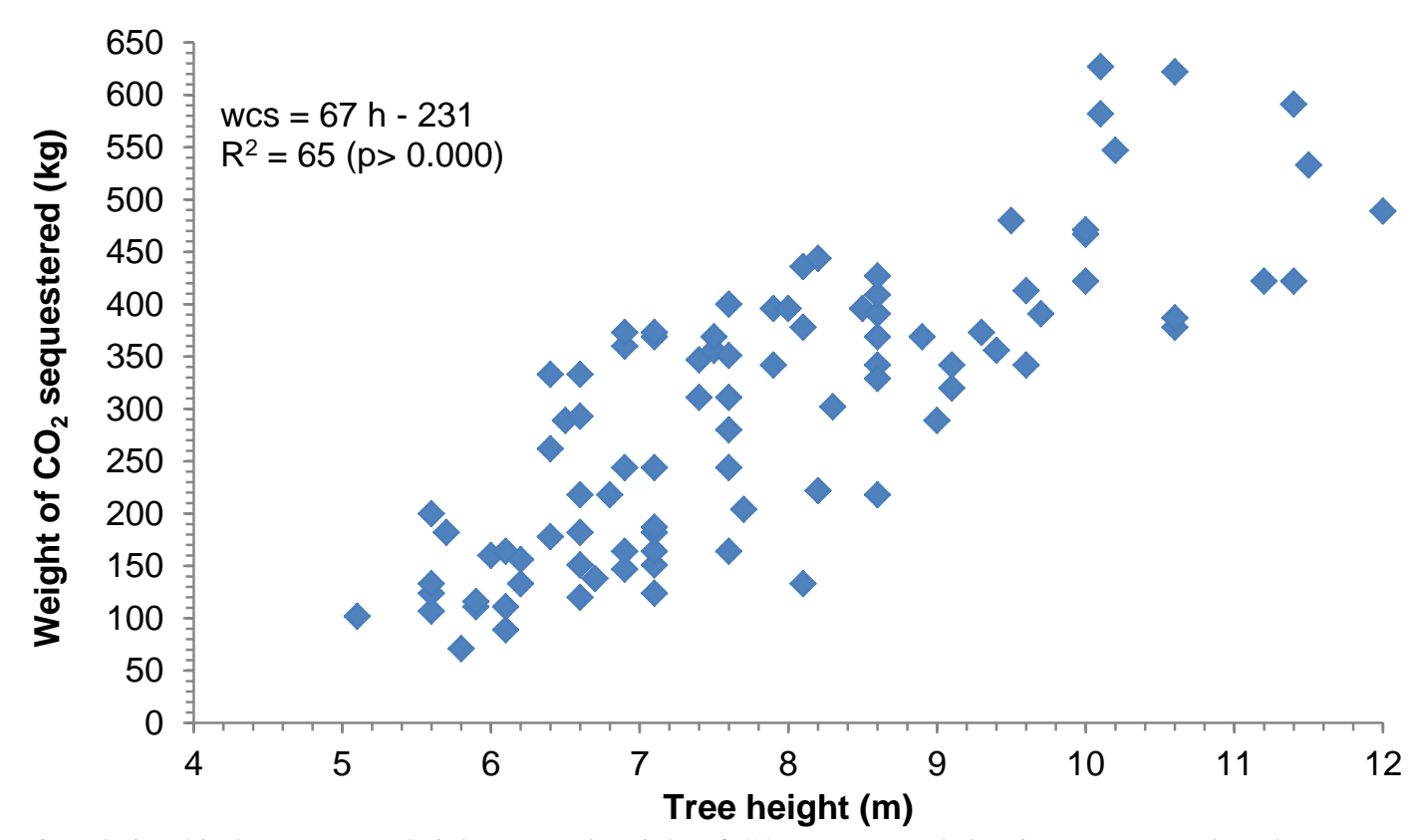

Figure 1. Relationship between tree height (m) and weight of $\mathrm{CO}_{2}$ sequestered (kg) in Acacia seyal (Del.) Brenan natural forest grown in Umbarona in the dry land of Sudan.

In Umbarona natural $A$. seyal forest, results of the correlation between tree height $(\mathrm{m})$ and weight of $\mathrm{CO}_{2}$ sequestered (kg.) was shown in figure 1. The figure showed significant fitting of relation and estimate of sequestered $\mathrm{CO}_{2}$ to $67 \mathrm{~kg}$ when the tree height increased by one $\mathrm{m}$. Applying the diameter at breast height $(\mathrm{cm})$ as independent variable to predict the sequestered $\mathrm{CO}_{2}$ was significantly gave $20 \mathrm{~kg}$ on one-cm increase in the diameter (Fig. 2). Nevertheless the relation confidence limits tended to diverge when the diameter grew to bigger than $27 \mathrm{~cm}$. Both interpreting variables showed a good interpolation as many of the values lies within the range of line of good fitting. 


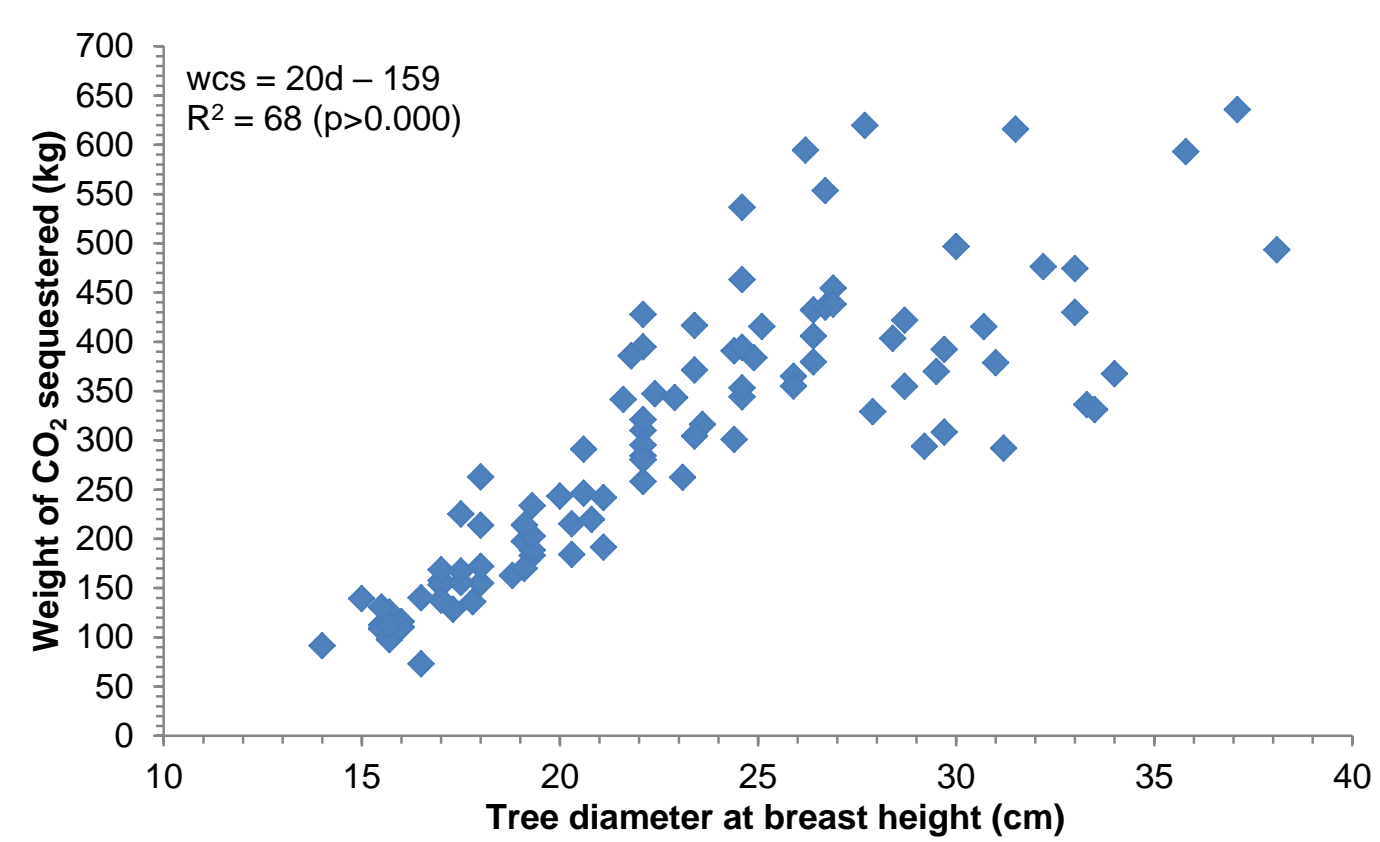

Figure 2. Relationship between diameter at breast height $(\mathrm{cm})$ and weight of $\mathrm{CO}_{2}$ sequestered $(\mathrm{kg})$ in Acacia seyal (Del.) Brenan natural forest grown in Umbarona in the dry land of Sudan.

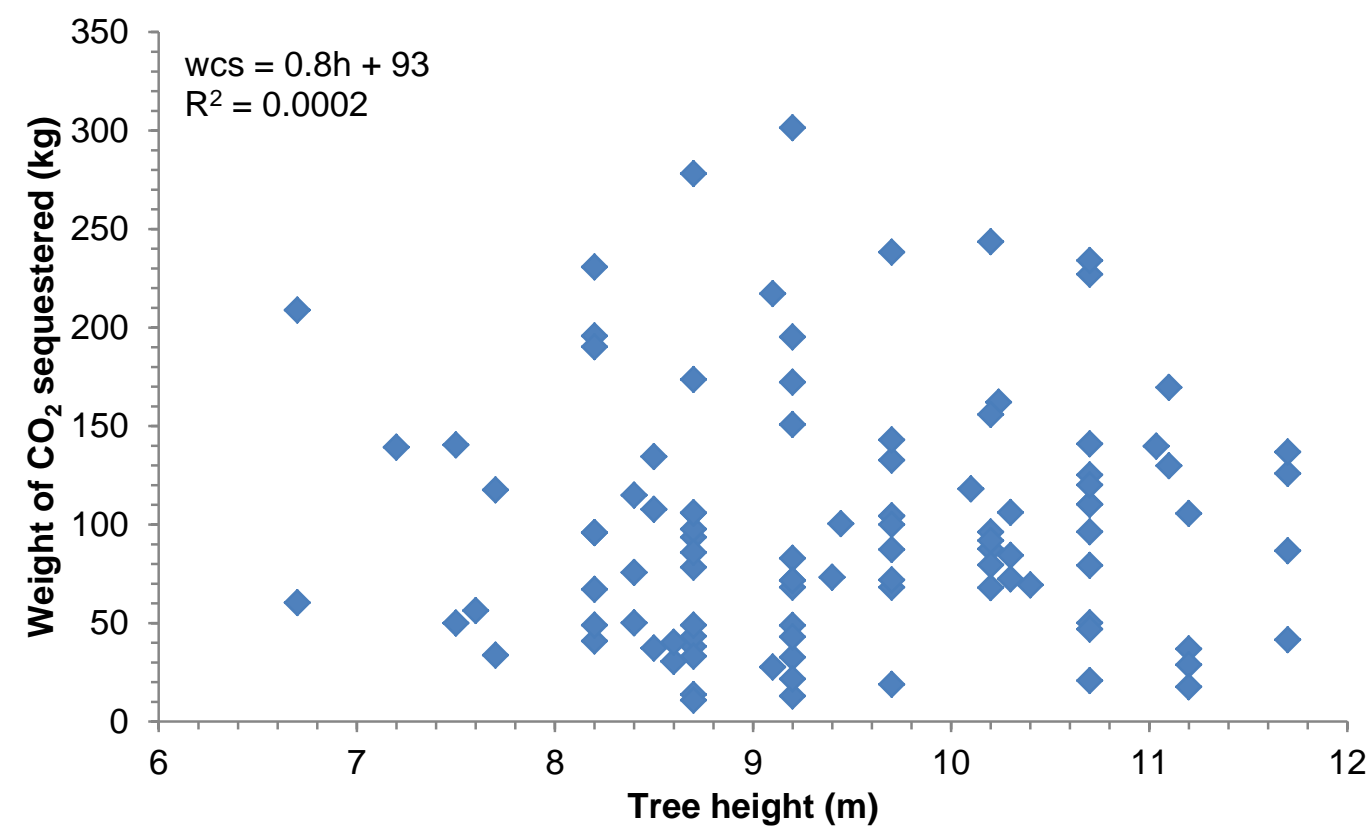

Figure 3. Relationship between tree height $(\mathrm{m})$ and weight of $\mathrm{CO}_{2}$ sequestered $(\mathrm{kg})$ in Eucalyptus microtheca (F.) Muell. plantation grown in Alamalhuda in the dry land of Sudan.

In E. microtheca plantation at Alamalhuda, correlation between the tree height $(\mathrm{m})$ and weight of $\mathrm{CO}_{2}$ sequestered $(\mathrm{kg})$ gave a model of $\mathrm{y}=0.8 \mathrm{x}+93$ (Fig. 3). This means that if the tree height increases by one $\mathrm{m}$, then the weight of $\mathrm{CO}_{2}$ sequestered $(\mathrm{kg})$ will increase by $0.8 \mathrm{~kg}$. The variables showed an extrapolation because many values on the scattered plot fell outside the range of the line of the best fitting. Correlation between the tree diameter at breast height $(\mathrm{cm})$ and weight of $\mathrm{CO}_{2}$ sequestered $(\mathrm{kg})$ gave a model of $\mathrm{y}=16 \mathrm{x}-82$ (Fig. 4). This means that if the diameter at breast height increased by one $\mathrm{cm}$, then the weight of $\mathrm{CO}_{2}$ sequestered (kg.) will increase by $16 \mathrm{~kg}$. The variables showed a good interpolation as many of the values lie within the range of the line of the best fitting. Therefore, the diameter at breast height is the best variable to give an estimation of $\mathrm{CO}_{2}$ sequestered by $E$. microtheca while the height is misrelated. In general, correlation analyses applied to both species reveal that the model "wcs $=\mathrm{a}+\mathrm{b} . \mathrm{DBH}$ " was the best predicting model in finding the correlation between the two biophysical parameters (total tree height and diameter at breast height) to the weight of $\mathrm{CO}_{2}$ sequestered. This aligns with previous researches (Rowntree \& Nowak 1991, Johnson \& Abrams 2009, Chavan \& Rasal 2010, Vashum \& Jayakumar 2012, Eneji et al. 2014). 


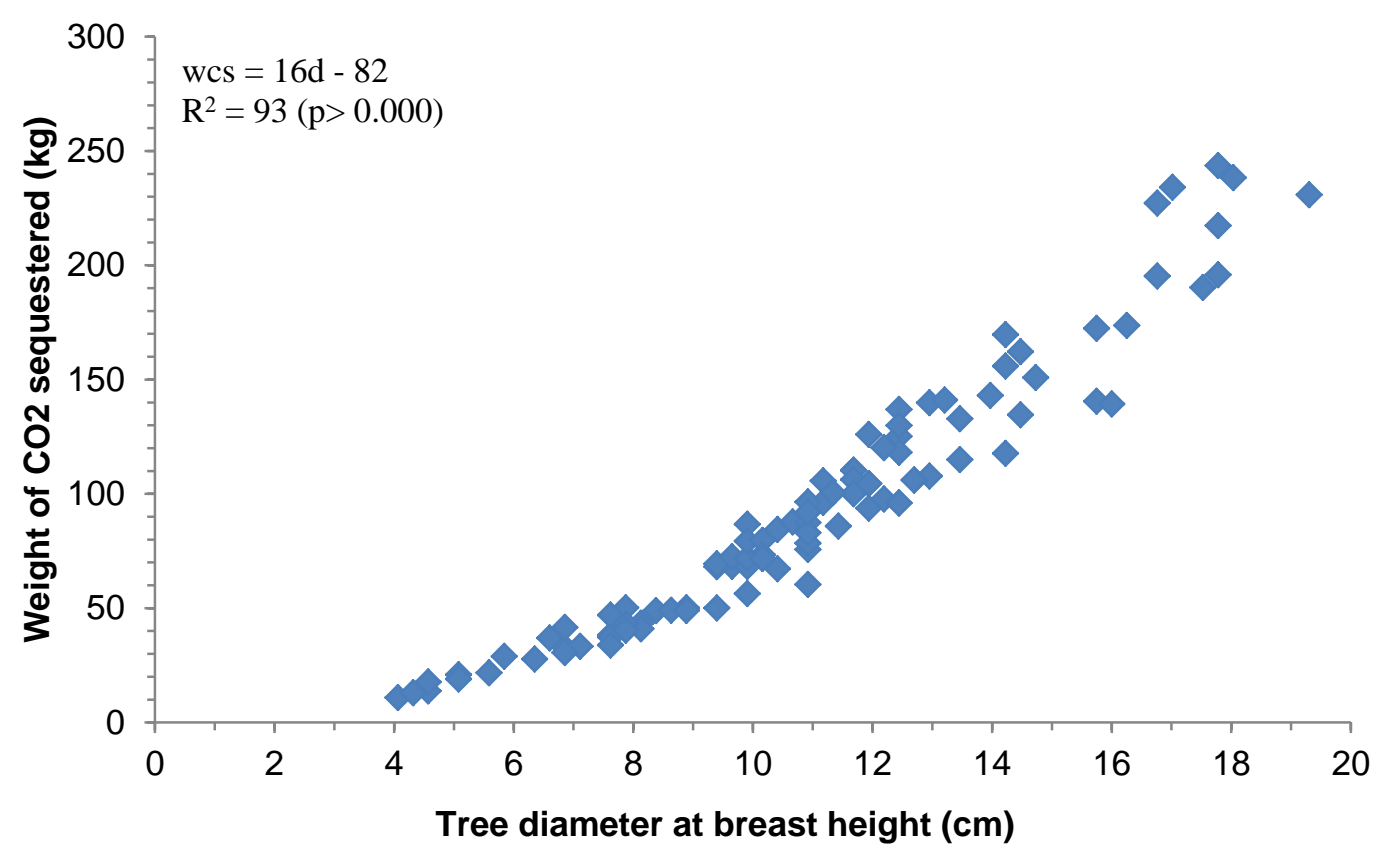

Figure 4. Relationship between diameter at breast height $(\mathrm{cm})$ and weight of $\mathrm{CO}_{2}$ sequestered $(\mathrm{kg})$ in Eucalyptus microtheca (F.) Muell. plantation grown in Alamalhuda in the dry land of Sudan.

\section{CONCLUSIONS AND RECOMMENDATIONS}

In conclusion, it was found that the model $[\mathrm{wcs}=\mathrm{a}+\mathrm{DBH}]$ gave the best fitting correlation between the weight of $\mathrm{CO}_{2}$ sequestered (wcs) and the diamter (DBH) for both species; $\mathrm{R}^{2}$ was $68 \%$ for $A$. seyal and $93 \%$ for E. microtheca. However, when the length of rotation and growth rhythm of the two species taken in consideration, the magnitude of carbon dioxide sequestered in the shoot biomass of E. microtheca was greater than that sequestered by A. seyal. This is suggesting the adoption of E. microtheca in plantation programs; however, many assumptions are raised by environmentalists criticize the allelopathic impacts of the Eucalypts on the fauna and flora compared to Acacia the leguminous genus that enriches the ecosystems. Sudan is in the midst of a genuine deforestation crisis. Most of the resources in northern, eastern and central Sudan have already been lost and the remainder is being depleted at a rapid pace. Therefore, more forest plantations will be vital ecosystems to serve as a carbon sink, specially the plantation that has the capacity to regenerate naturally after harvest. Moreover, the adoption of agroforestry practices because they are crucial ways in involving the community in conserving forest resources thereby improving the carbon dioxide sequestration potentials. In Sudan, the majority of agricultural schemes lack integration with forestry, thus, strong policies on agroforestry practices that positively and easily implementable with the strong and reliable effects of proper public awareness would back the plantation programs.

\section{ACKNOWLEDGEMENTS}

We are highly appreciating the logistic support provided by the Forests National Corporation at the Gezira State. We are also gratefully evaluating the help afforded by the staff of the Faculty of the Forest Sciences and Technology and those of the Department of the Environmental Studies and Natural Resources of the Faculty of Agricultural Sciences.

\section{REFERENCES}

Abetu D \& Bekele T (2019) Carbon stock in the Dirki woodland vegetation of Central Ethiopia: A case study in Ilu Gelan District, West Shewa Zone, Oromia Regional State. Tropical Plant Research 6(3): 438-451.

Aryal B, Bhattarai BP, Pandey M \& Giri A (2017) Carbon sequestration and CO2 mitigation in a burned ecosystem of Pinus roxburghii forest in Langtang National Park, Nepal. Tropical Plant Research 4(2): 297_ 306.

Babu KN \& Parthasarathy N (2019) Assessment of liana diversity and carbon stock in differently disturbed tropical dry evergreen forests of southern India. Tropical Plant Research 6(1): 74-89.

Badi KH, Elhouri A \& Bayoumi AMS (1989). The forests of the Sudan. Forests National Corporation and National Council for Research, Sudan. 235 p.

Bernal \& Victoria (1997) Colonial Moral Economy and the Discipline of Development: The Gezira Scheme and 
Modern Sudan. Cultural Anthropology 12(4): 447-479.

Birdsey RA (1992) Carbon Storage and Accumulation in United States Forest Ecosystems, General Technical Report. United States Department of Agriculture and Forest Service, Northeastern Forest Experiment Station, 59 p.

Chavan BL \& Rasal GB (2010) Sequestered Standing Carbon Stock in Selective Tree Species Grown in University Campus at Aurangabad, Maharashtra, India. International Journal of Engineering Science and Technology 2: 3003-3007.

Dafa-Alla DM \& Abidallha EH (2014) Management of Acacia seyal plantations for charcoal production: Local economies and sustainability. University of Khartoum Journal of Agricultural Science 22(2): 208-223.

Eneji IS, Obinna O \& Azua E (2014) Sequestration and Carbon Storage Potential of Tropical Forest Reserve and Tree Species Located Within Benue State of Nigeria. Journal of Geoscience and Environment Protection 2: 157-166.

Falkowski P, Scholes RJ, Boyle E, Canadell J, Canfield D, Elser J, Gruber N, Hibbard K, Högberg P, Linder S, MacKenzie FT, Moore B, Pedersen T, Rosenthal Y, Seitzinger S, Smetacek V \& Steffen W (2000) The Global Carbon Cycle: A Test of Our Knowledge of Earth as a System. Science 290(5490): 291-296.

Johnson SE \& Abrams MD (2009) Age Class, Longevity and Growth Rate Relationships: Protracted Growth Increases in Old Trees in Eastern United States. Tree Physiology 29(11): 1317-1328.

Kuimi TV \& Jayakumar S (2012) Methods to Estimate Above-Ground Biomass and Carbon Stock in Natural Forests - A Review. Journal of Ecosystem and Ecography 2: 116

Rowntree RA \& Nowak DJ (1991) Quantifying the Role of Urban Forests in Removing Atmospheric Carbon Dioxide. Journal of Arboriculture 17: 269-275.

Tahoor A, Musavi A \& Khan JA (2016) Biomass extraction impact on vegetation community structure in Kaimur wildlife sanctuary, Uttar Pradesh, India. Tropical Plant Research 3(1): 142-152.

Vashum KT \& Jayakumar S (2012) Methods to Estimate Aboveground Biomass and Carbon Stock in Natural Forest. Journal of Ecosystem and Ecography 2: 116.

Vivek P \& Parthasarathy N (2015) Diversity and carbon stock assessment of trees and lianas in tropical dry evergreen forest on the Coromandel Coast of India. Tropical Plant Research 2(3): 230-239. 